Provided for non-commercial research and education use. Not for reproduction, distribution or commercial use.

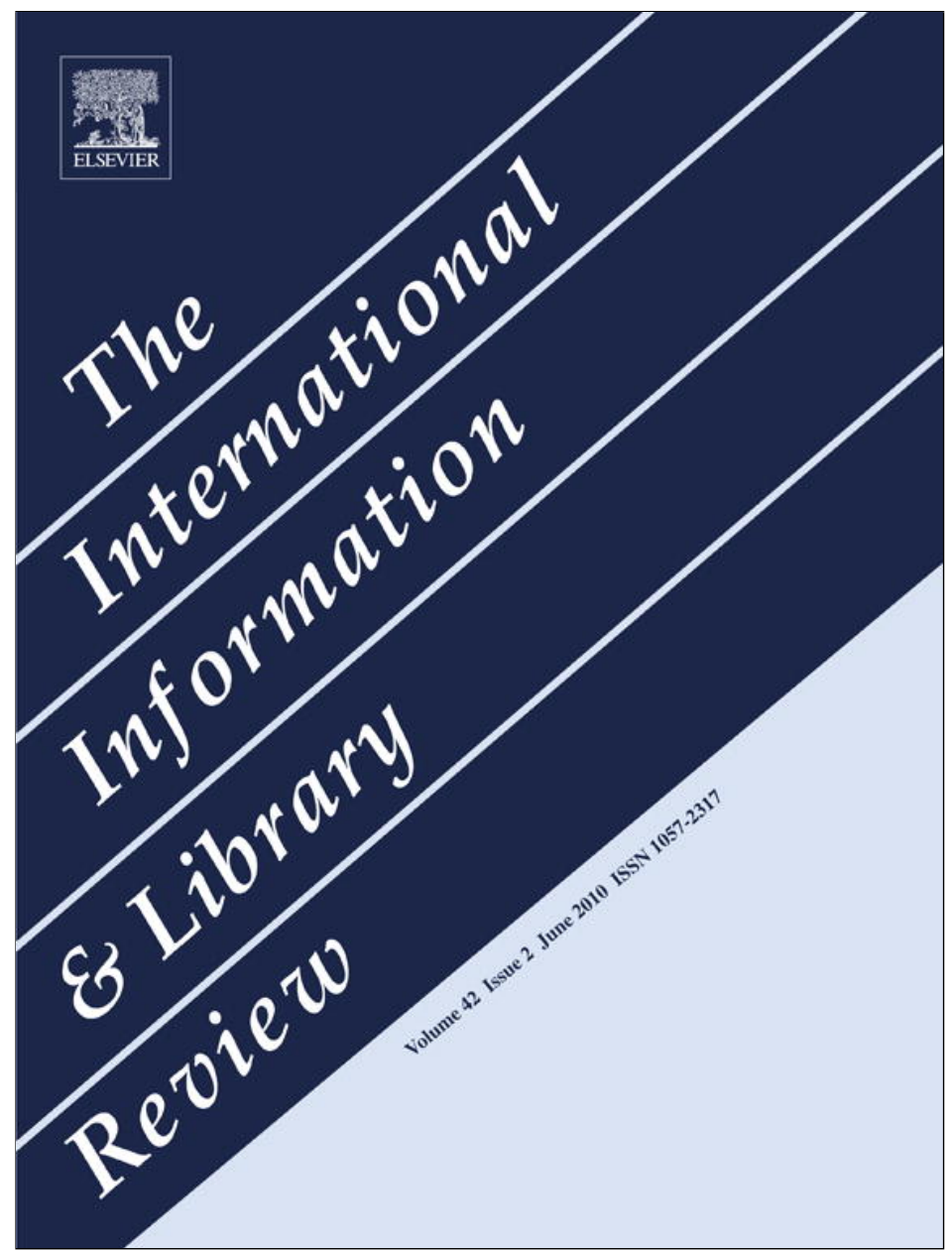

This article appeared in a journal published by Elsevier. The attached copy is furnished to the author for internal non-commercial research and education use, including for instruction at the authors institution and sharing with colleagues.

Other uses, including reproduction and distribution, or selling or licensing copies, or posting to personal, institutional or third party websites are prohibited.

In most cases authors are permitted to post their version of the article (e.g. in Word or Tex form) to their personal website or institutional repository. Authors requiring further information regarding Elsevier's archiving and manuscript policies are encouraged to visit:

http://www.elsevier.com/copyright 


\title{
Helping students become literate in a digital, networking-based society: A literature review and discussion
}

\author{
Nieves González Fernandez-Villavicencio a,b
}

\author{
aniversity of Seville, Seville, Spain \\ ${ }^{\mathrm{b}}$ University of Pablo de Olavide, Seville, Spain
}

\author{
KEYWORDS \\ Information literacy; \\ Media literacy; \\ Web 2.0; \\ Library 2.0; \\ Social networking; \\ E-literacy; \\ E-skills; \\ E-competency; \\ Digital natives; \\ Digital immigrants
}

\begin{abstract}
In this article the author presents and explains in detail the elements, including the pros and cons, of two contrasting schools of thought in one of the key debates which the author introduced as a teaching tool at the UNESCO Training-the-Trainers (TTT) Workshop that took place in Granada, Spain, 27-29 October, 2008. That debate, briefly stated, is whether or not Information Literacy (IL) and Media Literacy (ML), to be truly effective, should be pursued as complementary concepts, not in some way opposing concepts. One side in this debate argues that the two concepts have mutually inter-dependent goals, and therefore should be ideally learned and pursued together, and, most effectively, learned and pursued in the context of Social Networking and Web 2.0 tools and applications. The other side of the debate disagrees, and concedes that while the two concepts are indeed inter-related, they should be pursued largely independently, with only an occasional cross-reference. The debate is directly related to the role which Information Literacy and Media Literacy play in helping students become literate in a digital, networking-based society.

Without necessarily taking sides in the debate, although expressing a preference for complementarity, the author contends that it is absolutely essential that all persons (not just students) learn to become both Information Literate and Media Literate in this digital world in which we now find ourselves. Additionally, the author contends that Web 2.0 and Social Networking tools, such as Facebook, Tuenti (in Spanish context), MySpace and Twitter, including the rich portfolio of applications they encompass, can substantially assist people in achieving that goal.

The author presents a number of case examples to support her thesis, drawn largely from Spanish libraries and Spanish educational institutions that already are using Web 2.0 and Social Networking tools extensively to train people to become digitally competent. The ideas presented in this article, both the theories and best practices, are current insofar as the Spanish context is concerned, but the original arguments and supporting evidence put forth by the author at the aforementioned Granada UNESCO 2008 TTT workshop have been updated because of new developments and ideas that have occurred since the workshop took place. However, the original materials which were presented to and debated by the participants
\end{abstract}


and the expert-presenters, including the author, at the workshop, can be easily accessed at the public domain virtual space of the University of Granada website Universidad de Granada, 2008.

Two UNESCO TTT workshops, not just one, were actually organized at Granada. One was a traditional type held on-campus at the Library of Andalusia, and the other was an online, or a virtual workshop. During the on-campus workshop, as well as during the online workshop that preceded it, an interesting discussion took place between and among the participants and the expert-presenters concerning the necessity to redefine IL from its current, largely Web 1.0 focus and orientation, to the newer Web 2.0 focus, with emphasis on Social Networking. This article tries to capture, amplify and hopefully clarify the key points of this debate as it was presented by the author and then debated in the participant discussions which ensued (see http: / / www.slideshare.net/nievesglez/taller-alfin-unesco-sesion-paralela-alfin-20presentation).

(c) 2010 Elsevier Ltd. All rights reserved.

\section{Introduction, context and background}

The goal of Information Literacy is to help people become more efficient and effective in solving their problems and making their decisions in an increasingly digital networkingbased society rather than a physical document-based environment. Virtually no one disagrees that we live now in a digital networking-based society, as evidenced, for example, by the data collected by businesses such as Pew Internet \& American Life Project or Primary Research Group Inc. In Spain, recent reports show that the Internet has become a fundamental and integral part of Spanish life, and use of the Information and Communication Technologies (ICTs) has increased very significantly in Spain during the last few years (Fundación Telefónica, 2009; Gobierno de España, Secretaría de Estado de Telecomunicaciones y para la Sociedad de la Información, 2009; IAB Spain Research, 2009). More and more, we are all becoming dependent on the newest ICTs, and without them we can't efficiently and effectively access digital online content or interact with the many stakeholders and participants in what is often called the Global Information Society. Because of this, all governments, not just Spain, or not just Europe, believe that in today's world, countries must more sharply focus their efforts by investing substantial resources in acquiring and learning to efficiently utilize these new ICTs, and to develop new, major ICT-based projects in all sectors and in all spheres. Some people call these e-projects. In Spain examples of such pilot projects include Plan Avanza2 (Gobierno de España, Misterio de Industria, Turismo y Comercio, 2010) and Programa Escuela 2.0 (Gobierno de España, Ministerio de Educación, Instituto de Tecnologías Educativas, 2010). These actions are motivated by the Spanish government's conviction that ICTs are an essential and strategic element for the economic resuscitation of the country.

We bear testimony everyday to the truth of the above assertions when we use an ordinary first generation cell phone, or a newer smart phone, iPods, MP-3 players, Blackberries, eBooks, iPads, and the many, increasingly versatile and diverse, other kinds of hand-held mobile ICT devices. We also lend credence to the above assertions when we call attention to the many everyday examples of our increasing dependence on digital content instead of paper-based content, and on social collaborative online tools. It is hard to think of going back to an analog world, living and working in relatively isolated communication cocoons, faced with numerous information gatekeepers that frustrate rapid and easy information access. Because of using these mobile, hand-held ICT devices, each day brings an awakening of keen interest and curiosity from ordinary citizens as to their potential, as well as from policy-makers, educators, administrators and private entrepreneurs who are driving the research and development of the ICT industries including their application portfolios, making the necessary financial investments, and teaching the necessary skills.

The various research reports cited herein by the author highlight the growing importance of digital content created for Internet users, including ordinary citizens, businesses, the civil society and the educational system, all of which are major stakeholders and therefore contribute in a basic and substantial way to the development of the Global Information Society, and the ability of a country to survive, compete and prosper in the 21st Century.

The success of these practices and tools, aided by using the Internet and Broadband, is benefited greatly by the development of Web 2.0 and Social Networking tools, including improving the reading and writing competencies of users. This ability of co-authors to produce information products and services in a highly collaborative manner, and to then communicate with each other through digital network frameworks, is what some sociologists and behavioral experts call the new "culture of participation." True, this new way of socially interacting is primarily used at the moment by "digital natives," but, more and more, the concepts, the applications and the tools are being picked up and used not just by the younger generation, but also by middle aged and older generation citizens, sometimes called "digital immigrants," in a rather natural, everyday manner, through whatever free time they may be able to enjoy during the day or in the evening after work, as well as while engaging in social activities online rather than in person.

This dramatic change in the social interaction scene takes us to a new dimension that directly affects the need to update and reform some long-standing, traditional education paradigms, one of the most important of which 
involves the extension and consolidation of informal learning outside of the classroom, sometimes referred to as "invisible learning." To clarify the point, the learning process now, in a very real sense, takes place everywhere (not just in the classroom at school or at home). Thus, instead of taking the position that education should take place only in formal academic school settings and informal settings such as vocational schools that teach crafts, we should begin to think about education as a responsibility distributed through social networks of people and institutions, especially institutions such as libraries and schools, in close partnership between teachers and librarians, and between community centers and local residents.

In this situation, in order to become truly Information Literate, one has to rethink the idea of information itself, and come to the view that acquiring knowledge and information has a permanent strategic value, and has experiential and durable value, not just temporary and transitory value that has been traditionally acquired and utilized almost exclusively in an ad hoc fashion. Moreover, the traditional definitions and ways of measuring information products and services values and costs have to be redefined and updated in the context of the new definition of literacy itself in our modern digital context and environment. In this regard, some Spanish authors such as Marzal, Area, and Gros (2008), for example, discuss "Multiple Literacy," and others, such as Tiscar Lara (2009) or Juan Freire (2009), "Digital Competency."

We find ourselves confronted by an Information Society that is characterized by extreme ease in accessing information thanks to the sophisticated discovery tools, the abundance of digital content increasingly available online, oftentimes content produced by not just a single author but by many collaborating authors, and open and often free access to all types of information In the form of publications, institutional repositories, museums, archives, art galleries, etc. To find information is much easier today than in the past when information, except for the very rich and elite classes, was relatively scarce to come by and difficult to locate and acquire. Moreover, today people behave much differently toward information. They often need, and demand information quickly, concisely, accurately completely, authentically and reliably. In short, searching for and retrieving information that is needed is far easier than it used to be, but at the same time brand new challenges have been introduced. For example, one of the most difficult challenges is to evaluate the information once found. The World Wide Web but also the print world, is filled with thousands of bogus websites, with false and misleading information.

The accompanying figure, Table 1, "Towards Information Literacy Indicators,"(Catts \& Lau, 2008), contrasts key indicators and characteristics of the older Industrial Age economies with the newer Information Age economies.

In this situation, acquiring the skills that are necessary in order to understand and operate a variety of "information filters" is essential. These skills are critical in order to facilitate and guide how we can seek and then retrieve high quality and highly relevant information to help meet our information needs. Examples of information and message filters include spam and phishing blockers. This situation requires new skills to manage, retrieve, produce and communicate information in digital networks, an environment in which libraries and librarians play an increasingly strategic role. But libraries are no longer the only place with comprehensive and ready access to vast quantities of data, information and knowledge. The school, the workplace, the home, and the community center are places where preferably the information must be accessed. In the long term, this emerging situation of multiple access points may affect the very viability of libraries as social institutions, but that is another story beyond the scope of this article. The Chartered Institute of Library and Information Professionals, CILIP, (2004), in the UK defined Information Literacy as a collection of skills that permit one to recognize when information is required in the first place, and the skills needed to pinpoint the source(s) from which to obtain it, evaluate it, and use it efficiently. Today that definition requires a new, updated focus that embraces the new abilities and competencies required in order to manage digital information in the new Social Networking context. These new competencies include learning to use specialized tools to find, produce and share digital information, as well as the development of a positive attitude that welcomes, rather than fears or rejects, receiving and using digital information instead of conventional printed information in the form of documents and records. Other authors, including Cobo Romani (2009) have proposed new terms such as E-Literacy and E-Competency, to more appropriately term and define these new kinds of digital competencies. These authors also address in what ways learning methods could be incorporated into both formal and informal educational settings, with an eye to the needs of the labor market (into whose arms the new graduates will be placed). In this sense, the expansion of 21st Century ICTs is shaping up to be a much more complex phenomenon than the simple computerization (speeding up, simplifying and streamlining) of tasks, which was the case until now. The modern, highly competitive workforce demands highly skilled and educated employees, proficient in the use of ICTs, and able to manage information and knowledge. The interest that these new labor market demands is reflected in VIII Jornadas CRAI de REBIUN (Spanish University Library Network) which is dedicated to the advocacy of Information and Computer Literacy in the working world (REBIUN, 2010).

Due to these diversity of approaches a number of expert sources have been investigated in order to propose a new conceptualization (or at least an updating) of these key concepts and terms. Thus, a number of underlying concepts that each are closely related to the expression "E-Competency" are juxtaposed and elaborated in the accompanying diagram: E-Awareness; Technological Literacy; Informational (or simply Information) Literacy; Digital Literacy and Media Literacy. The inter-relationships among these five closely related concepts are graphically depicted in the accompanying image Fig. 1 (Cobo Romani, 2009, p. 20).

Some authors define Media Literacy as the sum of knowledge, skills and attitudes which citizens need to interact in a conscious, critical and active way within an increasingly complex, changing, and fundamentally "medialized world". These authors assert that everyone should be able to access and use the new media, oftentimes 
Table 1 Comparison of industrial and knowledge economies.

\begin{tabular}{|c|c|c|}
\hline Characteristic & Industrial economy & Knowledge economy \\
\hline Resources & Materials are scarce and expensive to access & Information is often widely available al marginal cost \\
\hline Usage & $\begin{array}{l}\text { Materials are depleted when used and } \\
\text { recycling is expensive }\end{array}$ & Information can be shared and may grow through use. \\
\hline Durability & $\begin{array}{l}\text { Materials are usually stable and do not } \\
\text { deteriorate over time }\end{array}$ & $\begin{array}{l}\text { Information needs to beupdated continuously and } \\
\text { quality can deteriorate rapidly }\end{array}$ \\
\hline Distribution & $\begin{array}{l}\text { Materials and Products need to be transported } \\
\text { and costs can determine both sites of } \\
\text { production and access to products }\end{array}$ & $\begin{array}{l}\text { Provided } 1 \mathrm{CT} \text { infrastructure exists, both information } \\
\text { (materials) and knowledge (products) can be } \\
\text { distributed widely }\end{array}$ \\
\hline Ownership and Law & $\begin{array}{l}\text { Products can be patented, access controlled } \\
\text { and taxes applied }\end{array}$ & Knowledge can be difficult to regulate and tax \\
\hline Pricing & $\begin{array}{l}\text { Value is usually fixed by inputs, labor and } \\
\text { transport costs }\end{array}$ & $\begin{array}{l}\text { Value is primarily determined by IP and can vary } \\
\text { depending on content }\end{array}$ \\
\hline
\end{tabular}

in real time and interactively, and to understand and to critically evaluate different aspects of alternative media, and their respective content, and to create communications in a variety of media (Nijboer \& Hammelburg, 2009).

The European Commission (2009a) recognizes the new challenges of the Global Information Society and recommends that everyone become literate in the new media because Media Literacy could substantially improve such widely diverse goals as the more efficient use of search engines, teaching students how to make their own movies, or how advertising works and how that concept might be incorporated into personal settings, not just organizational ones. Moreover, the International Telecommunications Union and elements of the U.N. System such as UNESCO, UNCTAD, and UNDP, and international NGOs, came together in May 2010 in Geneva to discuss next steps in moving the World Summit on the Information Society (WSIS) recommendations made at the baseline WSIS two meetings which were held in Geneva and Tunis in 2004 and 2005 forward.

According to Cobo Romani (2009), two very important abilities related to Information Literacy are evaluation (reflecting in order to make judgments about the quality, relevance, usefulness, efficiency, authority and timeliness of information) and integration (interpreting, summarizing, drawing conclusions, comparing and contrasting information from multiple digital sources).

Some authors suggest a new definition of information literacy that includes tool, resource, socio-structural, research, emerging technology, and critical literacies (RvC, 2005; Sharpless, Mitchell, \& Numbers, 2007). For Carolyn Carpan (2010), new competencies are understanding and articulating social networking sites and their roles, creating

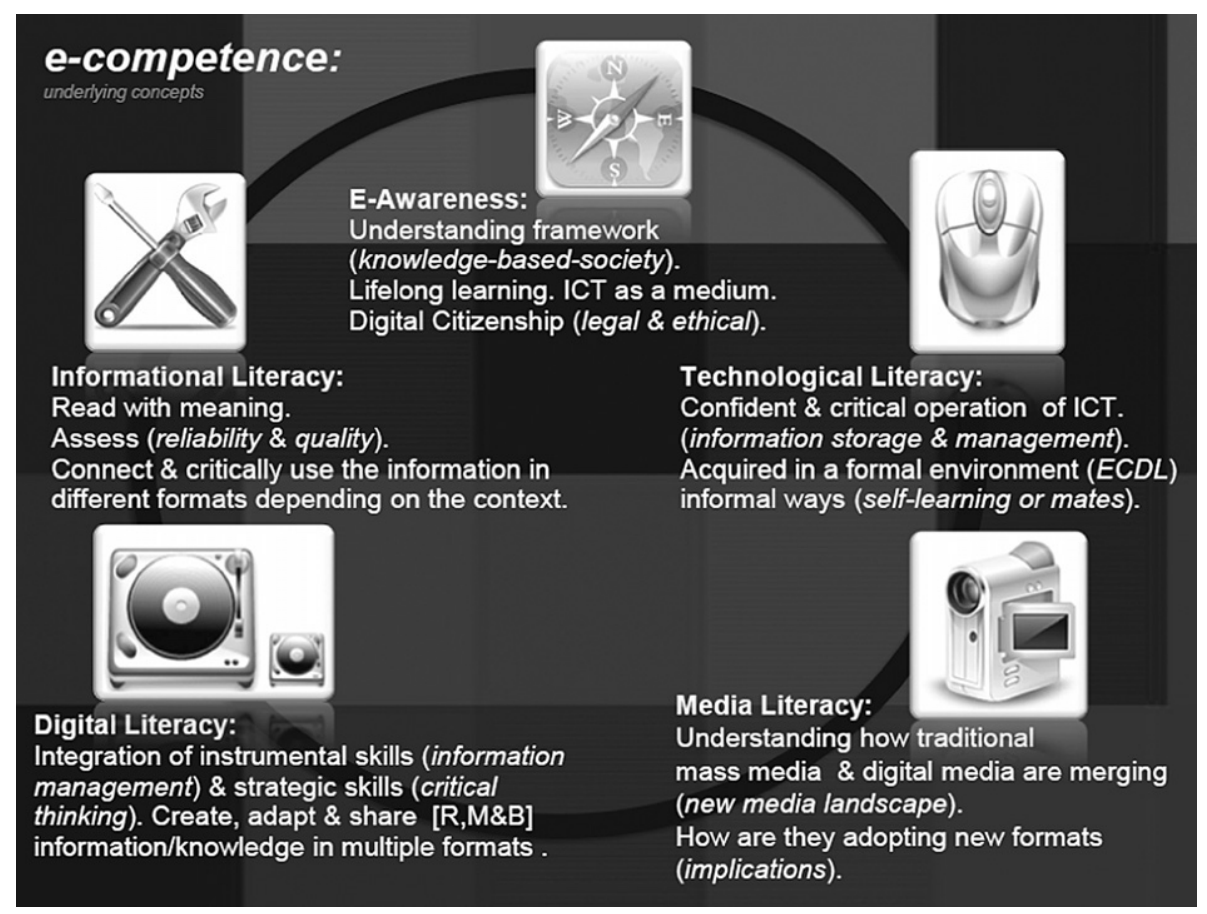

Figure 1 E-competencies and the five underlying concepts (Cobo Romani, 2009). 
content, evaluating information, applying information ethically and legally, searching and navigating, interacting, teaching, providing services, and flexibility.

For others like Spinarec and Zorica (2010), among new IL competencies should be "negotiation", defined as the ability to navigate across diverse communities taking into consideration multiple perspectives and their respective alternatives.

These new skills are required not just by students and learners, but also by teachers, administrators, government policy-makers and business employers. Those important stakeholder groups must come to consider the new literacies as strategically important digital skills for productive employment in any sector, and to conduct one's personal and family affairs effectively in everyday life, and to continue life-long learning.

It is also necessary to redefine the traditional role of libraries and the traditional modalities of user education and training. Training in IL must now incorporate the use of new ICTs and the widespread move from analog to digital media, and involve the establishment of collaborative partnerships with other stakeholder groups engaged in education and training. In short, there is a critical need to establish alliances and partnerships among all educational agents. Taking this need into account, the library should actively seek collaborations with the educational field and with media producers (Nijboer, 2009; Rollins, Hutchings, Goldsmith, Ursula, \& Fonseca, 2009).

Not only must information content be changed in form, access modalities and communication modalities, but also in the way content is transferred. We must change the way we teach digital skills through the use of collaborative tools, tagging, and the tools of the Social Web (Murphy and Moulaison, 2009). The use of the tools and approaches of the Social Web by teachers has become much more widespread.

According to the findings of one recent survey of librarians, the respondents actively used Web 2.0 technology in teaching Information Literacy courses "The adoption of Web 2.0 tools is manifested in a three-level. At the first level, $4 \%$ of librarians only use Web 2.0 tools for their own purposes without engaging students. At the second level, $84 \%$ of librarians, use Web 2.0 tools to facilitate the delivery of content to students, to publish content for students to access and interact with, or involve students in using the tools to complete coursework collaboratively or enhance interaction. At the third level, $38 \%$ of librarians draw upon certain features of the Web 2.0 technology to better illustrate IL concepts."(Luo, 2010).

Rebiun (2009), the Spanish university library network, held in April, 2009, a workshop on IL in practice, involving a representative number of Spanish university libraries which highlighted the social web tools for librarians to use in their IL programs. Although the use and number of Web 2.0 tools were not high, librarians recognized the progressive incorporation of these tools in their classrooms.

Reports such as the one developed by Javier Celaya (dosdoce.com) (2009), describe activities in the context of the libraries and schools in Andalusia (Spain), where the use of these tools is still a minority. Next, the author will review librarian training with respect to learning how to use the ICT tools and the applications of the Social Web.

\section{A brief summary of current literature}

The professional literature on the use of ICT tools and the social Web is very abundant and very recent, as one might predict. The changing conceptual inter-relationships between literacy, information, media, and Web 2.0 is coming at the same time that the Web is no longer what it was even a few years ago. User behavior is being radically transformed because of these changes. Blogs are among the first new Internet-inspired resources and dramatically underscore these changes, just since 2005. Numerous professional and expert presentations and conference speeches are now being made available far more extensively than they ever were before and often are published almost instantaneously, and even in real time. Several key monographs have pioneered in redefining the Information Literacy concept by applying Web 2.0 tools to teaching and learning Information Literacy far more effectively than previously.

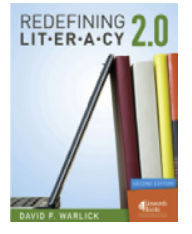

Among these is the work of David Warlick (2009), specifically his book "Redefining Literacy 2.0," which raises the need to redefine the basic term literacy itself in light of new ICT digital environment.

Miguel Angel Marzal et al. (2008), in the Spanish context, have studied the implications which the new Information Society concept has on the concept and practice of information literacy, and they predict a new concept will emerge in their book Alfabetizaciones Múltiples.

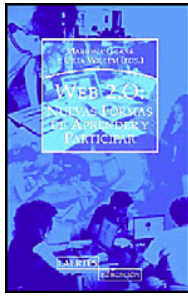

Tiscar Lara, a well-known Spanish blogger and college professor, is co-author of several books, among which is Web 2.0: nuevas formas de aprender y participar (Grané y Willem, 2009) in which he discusses the meaning of Media Literacy as a multiple and inclusive literacy, and which he places under the umbrella of Digital Literacy.

Perhaps the first work that addressed the direct relationship between Information Literacy and Web 2.0 (Godwin, et al. 2008), is the book by Peter Godwin and Jo Parker, Information Literacy meets Library 2.0. This book of readings, the result of the contributions of several noted authors, is intended to reflect on the benefits of the use of Social Web tools in Information Literacy teaching and learning. Godwin has updated his monograph on his blog Information Literacy meets Library 2.0 (Godwin, 2010) which updates the content of his original book and informs readers of new examples of effective Information Literacy practices. He also provides a very good current bibliography relating to this subject.

Other oft-cited authors who have studied the application of Web 2.0 and Social Networking tools to the training of Information Literacy include Sheila Webber and her research and teaching associates at Sheffield University in the UK, and 
her contributions can be reviewed in her blog - Information Literacy Weblog (http://information-literacy.blogspot. $\mathrm{com} /$ ) Also of interest is her page Sheila Webber in Netvibes (Webber, 2010b).

The author of this article also has a blog Bibliotecarios 2.0, (http://bibliotecarios2-0.blogspot.com) where she tries to illustrate these same advances but of course in a Spanish context as well as a website in Netvibes concerning the subject of Information Literacy 2.0 - Alfabetización Informacional 2.0 (González Fernández-Villavicencio, 2010b).

Gerry McKiernan is another very prolific author and contributor to various blogs concerned with this subject. One of them is focused on mobile libraries (McKiernan, 2010a) and another blog is concerned with social networks (McKiernan, 2010b). Both blogs are very interesting and McKiernan promotes his findings very actively using social networks such as Facebook.

Many articles and case reports have appeared on the concept of Media Literacy. One of the most important authors is Cobo Romani, 2010, author of the blog Ergonomic (http://ergonomic.wordpress.com/). Recently, he published a very important monograph concerning E-Competencies and their impacts on future employability (Cobo Romani, 2009) - Strategies to Promote the Development of E-Competencies in the Next Generation of Professionals: European and International Trends.

Jelke Nijboer and Esther Hammelburg (2009) also made an important contribution to the field in Extending Media Literacy: a new direction for libraries in New Library World 2010.

Alejandro Uribe is one of the most active professionals in the field of Information Literacy and its relationship with ICTs, specifically Web 2.0. He was one of the participants who attended the virtual phase of the UNESCO TTT workshop held in Granada, and contributed actively to previous forums, having made many contributions. His most recent paper (Uribe, 2009) on this subject was El conocimiento y reconocimiento de los modelos de comportamiento informacional: Un aspecto necesario para los servicios de información Web 2.0 y la Alfabetización Informacional-DHI desde las bibliotecas.

In the Spanish domain we should also highlight here an important report concerning the state of IL in Spanish public libraries, prepared by the Grupo de Trabajo sobre ALFIN from Consejo de Cooperación Bibliotecaria (2009), Hacia la alfabetización informacional en las bibliotecas públicas españolas, where it was learned that the scant presence of IL training activities in Spanish libraries was a big problem, and this report recommended the integration of social web tools in all educational activities.

Another important and very relevant achievement in the context of university libraries in Spain is the consensus reached among academic librarians and computer sciences authorities concerning the need to educate the university community in computer and IL skills ( $\mathrm{Cl} 2$ Competencias informáticas e informacionales). These findings and recommendations are published in the paper: Competencias Informáticas e Informacionales en los estudios de grado. (CRUE/TIC REBIUN, 2009).

The author of this article has recently published some articles (González, 2008, 2009a,b) regarding the relationship between IL and Web 2.0 tools and digital divide. One of them is ALFIN 2.0: Herramientas 2.0 en programas ALFIN en bibliotecas de la Universidad de Sevilla; and Qué puede hacer la biblioteca 2.0 por la inclusión digital. Also, the author has made several presentations on digital skills understood and taken as a mastery of technological tools, including the Social Web, and IL.

Andalucía, the largest region of Spain, has been extensively researched in the use, by schools and libraries, of Web 2.0 technologies in development plans for reading. The aforementioned report (Celaya, 2009), issued by dosdoce. com (one of the most prestigious Spanish consulting firms) and the results are published on the website of the Guild of Editors. This report concluded that while it is true that many researchers are pursuing some very interesting projects using these tools in libraries for training purposes, the impact is still very poor, but, nevertheless, the report makes a number of recommendations of special interest to us here "Uso de las nuevas tecnologías Web 2.0 en las actividades de fomento de la lectura en Andalucía".

\section{Methodology used to research and prepare the UNESCO TTT workshop training materials, including results obtained from literature searches}

As mentioned above, the author prepared and presented Information Literacy instructional materials at the 2008 UNESCO workshop in Granada. These involved the following:

- Review of the literature, including a detailed reading of the literature on Web 2.0 and its application to the teaching of Information Literacy. The most significant parts of the literature researched was reviewed above in this article;

- Practical experience as a teacher in the University of Pablo de Olavide and the organization of an Information Literacy plan for the Library of the University of Seville, and as a speaker at conferences and a teacher of various IL courses;

- Designed a web page with the tools Netvibes for IL 2.0 (González, 2010a); and

- Handout documentation and presentations, which were part of the UNESCO TTT workshop.

In researching the literature to discover the views of various experts who have authored articles and books in this area, the author found that the relationship between Information Literacy and Web 2.0 could be approached from two perspectives. To be literate in Web 2.0, means having the skills to manage and use these tools, to know the extent of their positive impacts as well as their limits, and to be curious and stay up to date on new applications emerging in the context of Web 2.0 and social networks.

But we should also address the Web 2.0 from the perspective of its application to training activities that a library organizes or in which it participates. The library has to carefully plan its introduction and utilization of Web 2.0 in either the traditional classroom setting, or in the context of Distance Learning, online courses, or in a workshop or 
a Webinar context. In this way we are, in effect, introducing the Information Literacy concept and IL best practices, but within a Web 2.0 and social networks context.

As a result primarily of these two approaches, the very paradigm of IL transforms.

Spiranec and Banek (2010) argue that "The emergence of new kinds of landscapes makes necessary new kinds of competencies. Such fundamental transformation are causing the appearance of anomalies in the current IL paradigm which could effectively be resolved through the introduction of a sub concept of IL: Information Literacy 2.0".

Decidedly, and following the same authors, the transformation in training methods and various forms of delivery of services merely constitute a subordinate determinant of these re-conceptualizations and it is then necessary to restructure, update and extend our views on IL and express these changes through the 2.0 extensión (Fig. 2).

Let's take each of these alternative approaches and contrast them in the context of different dimensions of the challenge.

Information literacy in the Web 2.0 context - the stakes, the stakeholders, and the arenas

The reader will by now no doubt recognize that the author takes the position that to become truly Information Literate means to learn to efficiently use ICT skills not only in a general Internet usage context, but also in the context of the Social Web (or Social Networking as the author has sometimes referred to it). This training should be addressed to some important but overlooked target groups.

First of all, even if Internet users consider themselves to be "Digital Natives," they often do not know nearly as much as they think they know, much less should know about the subject. Then are the "Digital Immigrants," newcomers to the Internet and the World Wide Web. This category often includes the unemployed and underemployed, and they have a great deal to learn about Web 2.0 tools.

Second, in the university library context, we have to train all students in the use of these tools, not only the freshmen or students in general, but also professors and teaching faculties. Digital media literacy continues its rise in importance as a key 21 st Century skill, but there is an ever-widening training gap between the introduction of the newest theories, practices and tools that faculty and teachers must cope with, and the actual employment of these new theories and practices. Often not seen as a priority for faculty or teacher training, Digital Literacy and Media Literacy are nonetheless a critical set of skills that must be learned not only by students but also by those who work with them in the educational setting. Faculty are beginning to realize that they are limiting their students by not helping them to develop and use Digital and Media Literacy skills across the curriculum. This challenge is exacerbated by the fact that it is not exactly crystal clear as to how to codify the skills or set standards for their measurement.

Some Spanish university libraries are offering this type of training at the university level, such as is the case of the Libraries of Humanities and Architecture at the University of Seville.

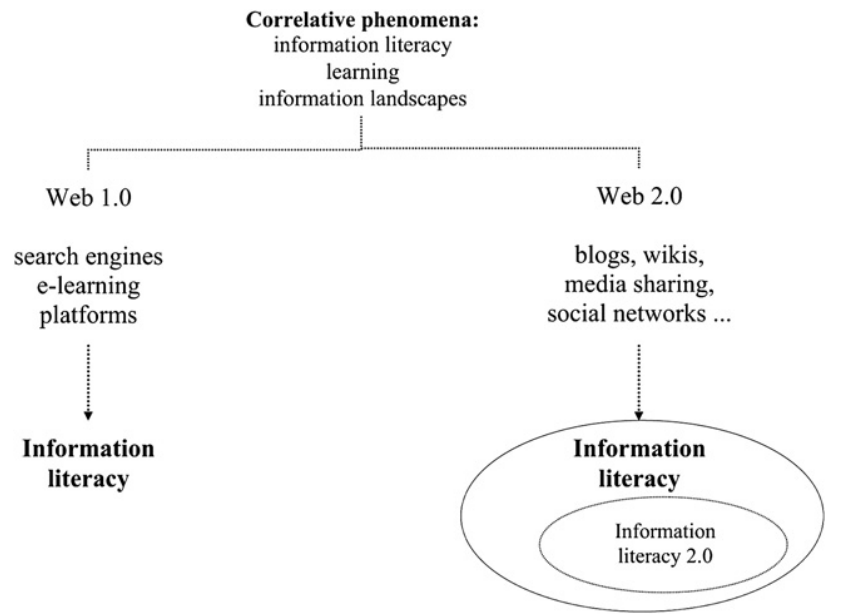

Figure 2 Correlative phenomens influencing the development of Information Literacy e.0 (Spiranec \& Banek, 2010).

The researchers are another group with a critical need to know what it means to be literate in the new concepts and contexts involved in learning subjects such as Science 2.0 or E-Resources 2.0.

Last but very important, librarians must be very fluent in the use of these tools and applications both from the standpoint of professional and personal applications.

Elvira Basibas Lapuz (2009) is the author of a recent presentation she gave at the 2009 IATUL Conference: Teaching Web 2.0 applications in the planning and development of Information Literacy programs: reaching out to librarians and information professionals. In this paper the author discuss the efforts exerted to teach Web 2.0 applications in the planning and development of IL to librarians, and she shows how Web 2.0 tools can be applied in the development of IL programs, including the use of blog and social networks sites to reach out to users.

In this regard, there have been many courses on Web 2.0 tools that have already been held, and continue to be held throughout Spain. For example, La Sociedad Española de Documentación e Información Científica, SEDIC, has organized a series of virtual courses and established Communities of Practice (CoPs as they are sometimes called) to address issues related to the use of social web tools by libraries and documentation centers. Among the most useful tools in this regard are the SEDIC blog (SEDIC Sociedad Española de Documentación e Información Científica, 2010a) and Wiki (SEDIC Sociedad Española de Documentación e Información Científica, 2010b) that support their virtual course offerings.

The coming together of Information Literacy and Web 2.0 is masterfully addressed by Sheila Webber, Peter Godwin, Gerry McKiernan and Alejandro Uribe (not only in their blog and Wiki contexts, but also through their contributions using Social Networks).

\section{Information literacy in the Web 2.0 context - the pedagogy}

Why do we need, and how do we use Social Web tools to teach Information Literacy? 
Currently it's not difficult to find significant examples of good uses of these tools in IL training activities. Year after year a number of good practices can be found not only in the library context but also in teaching in general. This is because to teach with this set of tools and methods improves Information Literacy practices and develops a set of "best practices." We can use them to innovate teaching methods and learning in the context of the higher education setting because of decisions of the Bologna process, which affects and guides educational reforms in all European countries.

Perhaps, one of the early and most important studies was LASSIE Project (2008a) (Libraries and Social Software in Education), a nine-month project, starting in March 2007 and funded by the University of London Center for Distance. The project explored new developments in Web technology commonly referred to as social software (or Web 2.0) and how these might be used to enhance library provision for distance learners. The project conclude that the training for using the tools of Web 2.0, and thereby improve the quality of online training that libraries offer and they offer the potential to enhance library services. The LASSIE project officially was concluded in December 2007 (LASSIE Project, 2010). However, progress can also be tracked via the project blog, which is currently still available (http://elearning.lse.ac.uk/blogs/socialsoftware/).

The LASSIE team undertook five case studies to explore how particular tools might enhance the learning experience of real distance learning students.

Case Study One explored whether traditional reading lists can be improved using social software. The project team explored the use of some online reading list or book list systems including: CiteUlike, LibraryThing and Bibsonomy, to present reading list information to students on a University of London distance learning course.

Meanwhile Case Study Two explored the Social Bookmarking tool Delicious, to collect useful resources for the project, but also as a way of directing students to web based resources. Several institutions in the U.S.A and Australia, and many in Spain, have developed web based subject guides using Delicious tools combined with Wikis.

Case Study Three focused on Information Literacy support for distance learners and produced a citing and referencing screencast. Using the Camtasia software, a training session with audio and screen capture was prepared.

Case Study Four explored libraries and blogging.

The final case study, Case Study Five, looked at the role of the Social Networking site Facebook, as a tool for librarians and for library services. This case study was largely literature based, although it also drew on experiences of project team members who joined Facebook. It includes some good practice guidance for librarians using Facebook, as well as highlighting library related applications in Facebook. It concluded that Social Networking tools are hugely popular with the Google generation and Digital Natives and many libraries are keen to explore how they might be used to promote their services. The final results of the project are available at a website (LASSIE Project, 2008b).

Several significant examples of using these tools in Information Literacy around the world include the use of blogs, Wikis, social media sites, tagging, bookmarks, virtual worlds, mobile, games, social networks, etc. One of the earliest and most interesting examples is Project P8 (Projet P8, 2009), a workshop organized under the Department of Visual Arts at the University of Paris VIII. Students are asked to complete the Wikipedia in the fields of Contemporary Art (including "digital"), design, architecture, history of art, film, etc. In this way, students learn to edit according to the requirements of Wikipedia, scientific format, and help create an encyclopedia which is more reliable. Undoubtedly, this should be a task for all those who are in some way involved in education, formal or informal, included librarians.

The use of social site Flickr, to share photos and videos, is very common in Information Literacy training. We can see its use by the University of Sheffield, Department of Information Studies, UK. They use these activities during a Week 1 Workshop (University of Sheffield, 2008) to introduce students to the idea of research. Students create an account on Flick, identify keywords, synonyms and terms related to a need for information, and create a controlled vocabulary as a disciplined information resource (e.g., using a database or thesaurus). This activity allows students to see how, for example, the cover of a book is oftentimes described differently by different people, and these differences in language and interpretation complicate the ability to sort and locate information. They use a Wiki to support their training and a blog as tools for demonstrating IL best practices (University of Sheffield, 2008, 2010).

Gerry McKiernan, whom the author has already mentioned several times, is a very knowledgeable librarian from the Library of lowa State University in the USA. He is the author of several blogs (Social Networking Sites, Spectrum $>$ Mobile Learning, Libraries and Technologies) and spaces in Facebook (2010a, b, c, d) and Ning (McKiernan, 2009), Where he showcases his experience in the use of technologies and utilities 2.0 in Information Literacy courses. Because, at colleges and universities today, students and staff are increasingly becoming members of Facebook, since the Summer of 2007 McKiernan has initiated a series of outreach projects using Facebook to directly promote IL Library programs and services to the community. These initiatives sought to inform students and faculty not only about the availability of core services offered by the reference and instruction department (e.g., book and journal selection, library presentations, research assistance) but also about the general library services provided by the library (e.g., interlibrary loan, library collections, reserve and media services).

McKiernan has used Facebook group discussions for this subject: Classroom Instruction in Facebook (McKiernan, 2010c) is a global umbrella which Facebook groups devoted to libraries use to complement and/or supplement formal library class instruction sessions. A particular focus of the group is the use of Facebook in association with basic library skills courses. The strategy is to first invite students to use the implementation of networks for Facebook to SciFinder Scholar class 101. Then to invite other students and teachers associated with the field of chemistry to be added to the Facebook SciFinder Scholar Interest Group (McKiernan, 2010d) and Facebook Chemistry-InformationSources-Information Group (McKiernan, 2010e). Finally, training sessions on key SciFinder Scholar is offered to all graduates and postgraduates from ISU. 
eSkills UNE and eSkills Plus are two training tools for improving informational competencies at the library of the University of New England, targeting students and postgraduates. For this second group, the library has created a group on the NING social network (eSKILLS Plus Meeting Place, 2010) that allows and facilitates interaction with the students and between students and offers more than a collection of resources to create an online community of practice.

Arizona State University in the U.S.A has been a trendsetter in providing video support for their students. They have a Library Channel on YouTube with a Library Minute series. It's a very important way to training Information Literacy because the students can follow classes through the videos and learn visually.

Second Life is a 3-D virtual world entirely built and owned by its residents. There are a great many libraries and information professionals with a presence in Second Life. One of them is Community Virtual Library (formerly Alliance Virtual Library), a non-profit library group dedicated to serving the residents of Second Life with library resources, reference services, and noteworthy events. Other important libraries in Second Life are McMaster University Library at Sheffield University. Recently, Sheila Webber organized Information Literacy Week in Second Life (Webber Sheila (2010a)).

McMaster and their place in Second Life and published a presentation about Information Literate Behavior in Second Life. In it she provides some analysis of interviews carried out by her students, asking (mostly) educators and librarians to think about a time they needed information for a Second Life activity. She has identified some types of information needs and, for each type, some ways in which the needs were addressed.

One of the most important tools for learning is the use of games. Libraries are using games to show students an easy way to become information literate. One of the most popular is a Trivial about IL from Greensboro University Library.

Most recently, the JISC-funded ARGOSI project used an Alternate Reality Game (ARG) to support the student induction process, with a particular focus on library and information skills. They've been working on an Information Literacy game at MMU - Viola Quest, which is now ready to play. ARGOSI had four key objectives: to enable students to meet the intended learning outcomes of the library and InfoSkills level one; to create social networks during the induction period; to improve student confidence in navigating the city and university campus; and to encourage students to engage in, and enjoy, the induction experience.

Finally, one of the more promising devices for training in IL are mobiles, and specifically in Spain has been pioneered by the Escuela de Organización Industrial (EOI). This institution is making these devices available as a means of communication with students, and also for digital skills training.

We could include in this article many other examples illustrating the use that libraries and information professionals are creating using the social web tools for their Information Literacy training activities. Many such examples were presented at the UNESCO TTT workshop and helped the author to see how some of the ones presented at that time did not have permanent value because they were primarily pilot or experimental in nature. Still others presented at the TTT workshop were later consolidated or transformed in different ways. And new examples later emerged.

The following are some specific examples of the use and availability of this set of Web 2.0 tools for libraries in Spain, primarily at the Seville University Library. We will also see some applications in their application to the teaching of Librarianship at the University Pablo de Olavide. Lastly, we will see the plans for training in the use of these tools for teaching digital skills to librarians who are members of the public library network of Andalusia (Spain).

\section{Author-participated projects initiated at the University library of Seville, Junta de Andalucía and University Pablo de Olavide (Seville)}

\section{At the library of Seville University}

At the University of Seville, librarians extensively use blogs and Wikis to communicate with colleagues, teaching faculties, students, and staff, for both day-to-day business and to promote and advertise their own training activities and offerings.

In Seville, librarians use IL blogs in two ways. First, to offer content related to their courses in collaboration with students (this is the case in the Biblioteca de la Escuela de Empresariales, School of Business Library, (Sevilla, 2010), for example) but also for assessing student learning through Edublogs, in collaboration with faculties (the case of Health Sciences, Biblioteca de Centros de la Salud (Sevilla, 2010a). Blogs use is very popular among librarians and this is an important tool used both for training and to promote the library. Librarians at the University of Seville were among the first in Spain to use blogs for this purpose several years ago (Biblioteca, 2010a).

Another useful tool in the library of the University of Seville is the use of Wikis. As already mentioned, Wikis are used for multiple purposes, but in relationship to IL the most important use is as subject guides (in combination with tags from Delicious bookmarcks) or to support IL in the context of various academic subjects. This format allows students and teachers to participate in creating content and initiating discussions between them and with librarians, on different topics. Of great impact was the Wiki entitled "Cine y Medicina" (Sevilla, 2010b), managed by the Library of the Health Centers, and the Wiki entitled "Innovación docente" (Sevilla, 2009) managed by the Humanities Library. Librarians are more or less continuously creating Wikis for these purposes, and one of the most recent is the Wiki of the School of Communication entitled "Wikicomunica" (Sevilla).

The use of Wikis is widespread but there is no uniformity as to the chosen software. Most libraries use mediaWiki for the guides by subject, others use pbworks, and just one (to the knowledge of the author) is using Wikispaces. The full list of Wikis for subject guides can be seen on the website of the library (Biblioteca, 2010b). 
In relation to reference services, librarians have initiated a new virtual reference service with a chat feature (González et al. 2009). They are using the open source program LibraryH3lp (LibraryH3lp software, 2010), the profile of which has been emulated as a template by a number of other libraries, (e.g., Complutense of Madrid in Spain) and which are often interested in other libraries outside Spain (e.g., Cardiff in Wales in the UK). While all librarians share general attention to the chat modality, they have established different kinds of chat profiles, such as one of them to address general questions from the catalog "FAMA" and another five distributed by five thematic areas (Biblioteca, 2010c), which are the five main thematic areas of the University of Seville.

To encourage librarians to participate in a chat, each month a podium is manned by knowledgeable librarians and is one of the most actively attended events at the library (Fig. 3).

Social Networks are tools of potentially great impact on society and are highly recommended for use in educational activities. In the Business School librarians are implementing the use of Twitter and Facebook to communicate better with users, including the promotion of training activities on IL.

Libraries have created different profiles on Facebook and Tuenti, the Social Network extensively used by Spanish university students, as well as Twitter. These applications help to keep users informed of the various activities of the library, and serve to promote the courses offered from the library. The teaching support section of the library has an account on Twitter, ALFINBUS, as a means of communication by teaching librarians, as well as wiki WikiAlfin (Sevilla, 2010d) and a space on Netvibes aforementioned (González, 2010b) with information about IL.

The library staff have translated and adapted to the Spanish context the excellent Information Literacy game created by Greensboro University. This game is used in digital skills training for new students (Sevilla, 2010e).

The library has created a new program for freshmen in technological and literacy competencies, in collaboration with the University's computer science department. In this way students acquire a basic level of digital skills, needed to be digital fluency in educational settings: knowledge of computers, WiFi, Web 2.0, digital identity, information management, evaluation, critical thinking, information ethics and legal digital privacy challenges, and source authentication and reliability. This is a rather fantastic collaborative effort between university departments for training in digital skills for the entire university community. ${ }^{1}$

\section{At the Junta de Andalucía}

At the Junta de Andalucía (the geographic region of which Seville is the capital city), a new program was started, "Plan Alba". This plan is an initiative of the Service Book, Archives and Libraries of the Ministry of Culture of the Andalusia. This service is working on this ambitious project which is aimed at digital skills training in management of information, and information competency improvement throughout Andalusia. It reaches out to both users and nonusers of the library network. This project has resulted the creation of a range of training opportunities, including workshops and other initiatives, launched by the librarians of the public library network in Andalusia, in collaboration with various kinds of public and private groups and entities, under the coverage of the Service Book.

As an overall theoretical framework, the Junta de Andalucía developed a Framework Document and Action Plan at the beginning of its efforts in this direction. Following that, the Junta planned a number of specific objectives which follow these main operational lines:

1. Training for the librarians at public libraries in digital skills so that they can offer courses or training activities for users and non-users of their libraries, and conduct their own initiatives for instruction;

2. Promote the creation of a repository of support materials and best practices for planning and delivery of training activities in digital form, primarily through the Project Wiki (Plan Alba, 2010);

3. Promote the creation of a Technology Center to advocate, support, and monitor the training activities undertaken by public librarians;

4. Consolidating a stable supply of digital skills training,, away from the current sporadic situation.

5. Support the funding and dissemination of initiatives, ideas, digital skill training, carried out by the Andalusian libraries through the organization of a competition of best practices and innovative ideas;

6. Foster collaboration with other Andalusia's institutions such as Guadalinfo Computer center; and

7. Establish and maintain training offers in virtual ways to librarians from Andalusia, from which they could go on to complete their learning, as well as offer more advanced and specific microcourses, which also would have access to the projects carried out by libraries and considered best practices.

During the first part of the First Action Plan, no less than 18 editions and versions of the basic training course in digital skills (Web 2.0 and Digital skills), were provided in all major cities in Andalusia by experts in these areas. A Wikirepository of materials was created as an integral part of the project, containing the "sketches of training activities" which librarians in the first phase of the training created and conducted as permanent evidence of the course content and results achieved.

\section{At the University Pablo de Olavide}

At the University of Pablo de Olavide a new program was initiated to train freshmen from the Humanities discipline in TIC for Humanities, in computer and literacy competencies. The author is one of the faculty members who participated in this program. This program also, like most of the others we have covered above, created and used a Wiki (Universidad Pablo de Olavide. Grado de Humanidades,

\footnotetext{
${ }^{1}$ You can see more information in website page http://bib.us.es/cursos_orientacion/index-ides-idweb.html.
} 

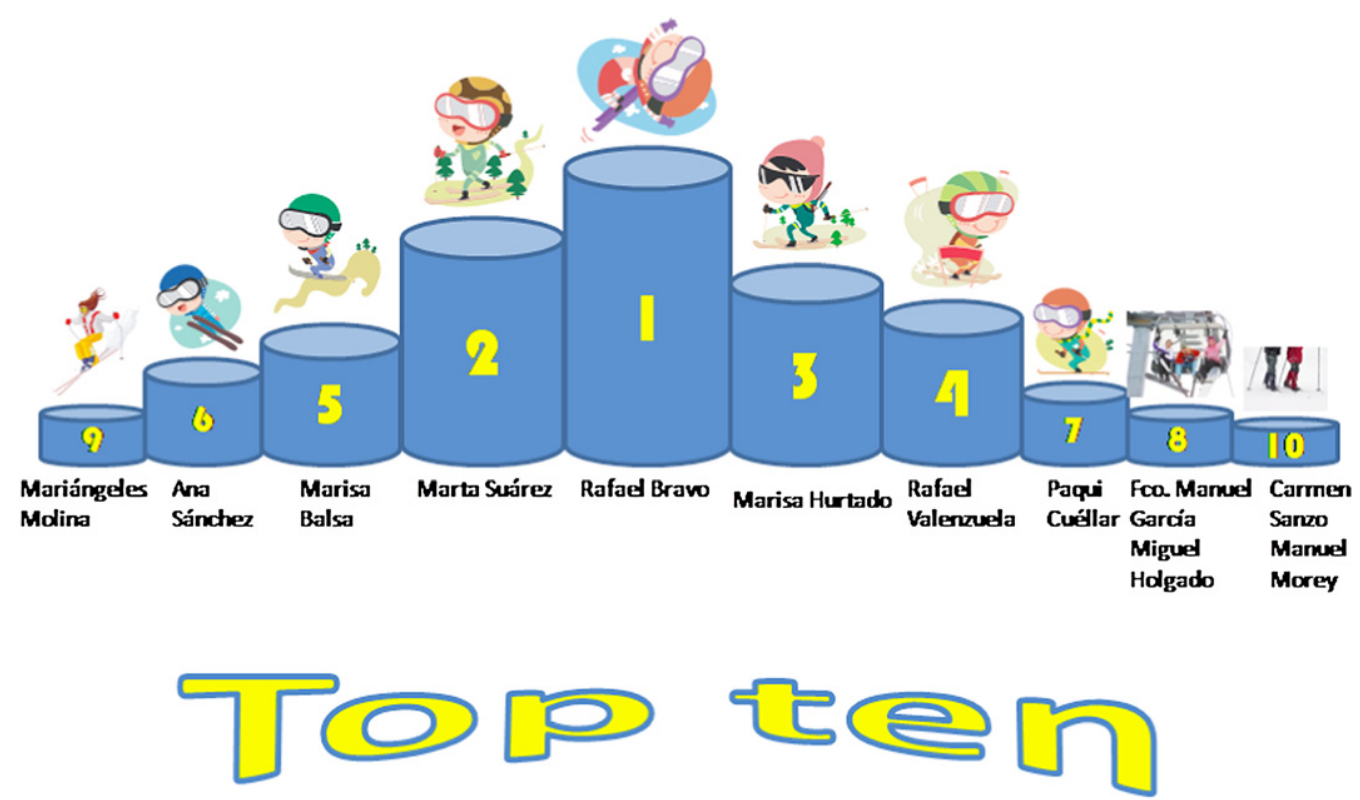

febreno 2010

Figure 3 Podium most active librarians with chat.

2010a) as a vehicle to share with students both ideas and materials.

Students are required to write their essays on the Wiki and share their knowledge with other students. To keep in touch with teachers, they use a Twitter account (Universidad Pablo de Olavide. Grado de Humanidades, 2010b) The students very much appreciated training in the use of these tools, and indicated afterward that they believed this training would serve them well for the rest of their academic stay.

Another successful initiative was the master teacher training school in which students are taught to become familiar with these tools, and how they can be used for digital skills training.

Finally, at this university, the author teaches the subject "Librarianship," but with a strong focus on digital content and digital skills. Students must show they have learned course content not just through class participation and examinations, but also through their comments and reflextions which they write in their personal blogs (Universidad Pablo de Olavide. Área de Biblioteconomía y Documentación, 2010). Also, students are required to upload their final class presentation to Slideshare, and contribute writings to the Wiki.

Many of the examples presented here, were discussed during the UNESCO TTT workshop held in Granada. From those workshop discussions, several librarians were keen to know in depth the social web tools and their application to IL training activities carried out by libraries.

After the workshop, the author taught courses on Web 2.0 for IL librarians of libraries in different Spanish cities including Madrid, Valencia, Tenerife, Murcia, Granada, Cadiz and Malaga. The impact of Web 2.0 in Spanish libraries can be seen on a Google map created for this purpose and the reader is invited to view the author's Google map on Spanish libraries 2.0 (Bibliotecas 2.0 en España).

\section{Conclusions}

The author would like to conclude by echoing the recommendations of the European Council (EC, 2009b) with regard to the importance of learning Media Literacy and Information Literacy in the 21st Century digital environment in which we find ourselves in order to bring about both a more competitive audiovisual and content industry in Europe, as well as a more inclusive Information and Knowledge Society in each country and in the European region as a whole.

The author has tried to argue that there are many reasons why Information Literacy, Media Literacy, Web 2.0 tools and Social Networking should be viewed as complementary concepts, and their respective applications and tools made to mesh together smoothly. One reason is because of the radically changing ways in which information creation, communication, searching, retrieval and utilization are taking place. The transition from paper-based print publications to eBooks is just one example, and the traditional publishing industry is in great difficulty at the moment because it has not yet found a viable way to cope with this transition. Another reason is because of the dramatic and widespread impact the new ICTs are having on all facets of life - life-long learning, not just in school, finding and keeping a job, raising a family, and so on. A third reason is because of the shifts in the traditional ways people use, access, produce, and share information, even in the short span of a few decades. For example, in some regions of the world the oral tradition is still paramount, and using the new 
ICTs in those environments is creating great difficulties. A fourth reason is because the utilization of Web 2.0 tools, Social Networking in helping to teach and to understand Media Literacy and Information Literacy all helps citizens considerably to not only learn and understand better, but also to spread the word with their friends and colleagues, as to how indispensable learning how to manipulate information is for every citizen in this Digital Era. And, finally, because the specific goals and purposes unique to each of the three concepts (Social Networking, Information Literacy and Media Literacy) could be greatly enhanced if they were viewed as being mutually supportive, complementary paradigms, not competing ones - each being pursued in virtual isolation without regard to the other.

Andalusia

\section{References}

Lapuz, Elvira Basibas (2009). Teaching Web 2.0 applications in the planning and development of information literacy programs: reaching out to librarians and information professionals. 2009 IATUL Conference. Retrieved 18.04.10, from. http://www.iatul. org/doclibrary/public/Conf_Proceedings/2009/Lapuz-text.pdf.

Carpan, Carolyn (2010). Introducing information literacy 2.0. College \& Undergraduate Libraries, 17(1), 106-113.

Catts, Ralph, \& Lau, Jesus (2008). Towards information literacy indicators. Unesco: Paris. Retrieved 18.04 .10 from. http:// www.uis.unesco.org/template/pdf/cscl/InfoLit.pdf.

Celaya, Javier, \& (dosdoce.com). (2009). Uso de las Tecnologías Web 2.0 en las actividades de fomento de la lectura en Andalucía. 18.04.10, from. http://www.pactoandaluzporellibro. com/portal/media/AVANCE_INFORME_WEB_2_0.pdf? phpMyAdmin = sthaZgoiCcZSHba7Zd6-8JCF8Ia.

Chartered Institute of Library and Information Professionals. (2004). Information literacy: definition. Retrieved 18.04.10, from. http://www.cilip.org.uk/get-involved/advocacy/ learning/information-literacy/pages/definition.aspx.

Cobo, Romani, \& Juan, Cristobal (2009). Strategies to promote the development of E-competencies in the next generation of professionals: European and international trends [Monograph No. 13]. Retrieved 16.04.10, from. http://www.scribd.com/ doc/24956423/Strategies-to-Promote-the-Development-of-Ecompetencies-in-the-Next-Generation-of-Professionals-EU-andInternational-Trends.

Cobo, Romani, \& Juan, Cristobal (2010). Ergonomic Weblog. http://ergonomic.wordpress.com.

Consejo de Cooperación Bibliotecaria, Grupo de trabajo sobre ALFIN. (2009). Hacia la alfabetización informacional en las bibliotecas públicas española. http://www.rebiun.org/doc/documento_ competencias_informaticas.pdf Retrieved 18.04.10, from.

CRUE/Tic Rebiun. (2009). Competencias Informáticas e Informacionales en los estudios de grado. Retrieved 18.04.10 from. .

eSKILLS Plus Meeting Place. (2010). NING social network. http:// eskillsplus.ning.com/.

European Council (EC). (2009a). Media literacy. Retrieved 16.04.10, from. http://ec.europa.eu/avpolicy/media_literacy/index_en. htm\#what.

European Council (EC). (2009b). Council conclusions on media literacy in the digital environment. 2978th education, youth and culture Council meeting Brussels, 27 November 2009, Retrieved 18.04.10, from. http://ec.europa.eu/avpolicy/media_literacy/ docs/recom/council_adoption_ml_27112009.pdf.

Freire, J. (2009). Módulo transversal para la adquisición de competencias digitales. Retrieved 18.04. http://www.slideshare. net/innovaciondocenteunia/mdulo-transversal-para-laadquisicin-de-competencias-digitales 10 , from

Telefónica, Fundación (2009). La Sociedad de la Información en España 2009. Retrieved 16.04.10, from. http://e-libros. fundacion.telefonica.com/sie09/.

España, Gobierno de (2010). Ministerio de Educación, Instituto de Tecnologías Educativas. Programa escuela 2.0. Retrieved 16.04.10, from. http://www.educacion.es/aula2010/modernizacion/escuela2p0.html.

España, Gobierno de (2010). Ministerio de Industria, Turismo y Comercio. Avanza 2. Retrieved 16.04.10, from. http://www. movimientoavanza.es/plan-avanza/.

España, Gobierno de, \& Secretaría de Estado de Telecomunicaciones y para la Sociedad de la Información. (2009). La Sociedad en Red: Informe anual de la Sociedad de la Información en España 2008. Retrieved 16.04.10, from (Edición 2009).. http://e-libros.fundacion.telefonica.com/sie09/.

Godwin, Peter (2010). Information literacy meets library 2.0 Weblog. http://infolitlib20.blogspot.com/.

Godwin., Peter., Parker., \& Jo. (Eds.). (2008). Information literacy meets library 2.0. Cornwall (Great Britain): Facet Publishing.

González Fernández-Villavicencio, Nieves (2008). n 92-93, Julio-Diciembre 2008, pp. 11-31 Retrieved 18.04.10 from ALFIN 2.0: Herramientas 2.0 en programas ALFIN en bibliotecas de la Universidad de Sevilla. Boletín de la Asociación Andaluza de Bibliotecarios. http://www.aab.es/pdfs/baab9293/92a1.pdf.

González Fernández-Villavicencio, Nieves (2009a). Qué puede hacer la biblioteca 2.0 por la inclusión digital. Educación y biblioteca, 21(172), 107-113.

González Fernández-Villavicencio, Nieves (2009b). Competencias informáticas e informacionales. II Conferencia Internacional sobre Brecha Digital e Inclusión social. Madrid, 28-30 October. Retrieved 18.04.2010. http://www.slideshare.net/nievesglez/ competencias-informticas-e-informacionales from.

González Fernández-Villavicencio, Nieves (2010a). Bibliotecarios 2.0 Weblog. http://bibliotecarios2-0.blogspot.com.

González Fernández-Villavicencio, Nieves (2010b). Alfabetización informacional 2.0 netvibes page. http://www.netvibes.com/ nievesglez\#Aprendizaje_informal.

González-Fernández-Villavicencio, Nieves, Barrera-Gómez, JuanAntonio, Gómez-Fernández, María-José, Moscoso-Castillo, Miriam, Santos-Flores, Victoria, \& Suárez-Samaniego, Marta (2009)Referencia virtual en la Biblioteca de la Universidad de Sevilla: una experiencia colectiva. El profesional de la información, Vol. 18. (6), pp. 633-641.

Grané, Marionay, \& Willem, Cilia (2009). Web 2.0: nuevas formas de aprender y participar. Barcelona: Laertes.

IAB Spain Research.. (2009). Estudio sobre redes sociales en Internet. Retrieved 16.04.10, from. http://www.iabspain.net/ descargas/descarga. php?id $=128$.

Lara, T. (2009). Competencias Digitales y Conocimiento Abierto. http://www.slideshare.net/tiscar/competencias-digitales-yconocimiento-abierto Retrieved 18.04.10, from.

LASSIE Project. (2008a). Libraries and social software in education page web. http://clt.lse.ac.uk/Projects/LASSIE.php.

LASSIE Project. (2008b). Project overview and key findings. Retrieved 18.04.10, from. London: London School of Economics and Political Science. http://clt.lse.ac.uk/Projects/LASSIE_ summary.pdf.

LASSIE Project. (2010). LASSIE Project blog. http://elearning.lse. ac.uk/blogs/socialsoftware/.

LibraryH3lp software. (2010). LibraryH3lp Web site. https:// libraryh3lp.com/admin/.

Luo, Lili (2010). Web 2.0 integration in information literacy instruction: an overview. The Journal of Academic Librarianship, 36(1), 32-40. 
Marzal, M. A., Area, M. \& y Gros, Begoña (2008). Alfabetizaciones y tecnologías de la información y la comunicación. Madrid: Editorial Síntesis.

McKiernan, Gerry (2009). Library 2.0. Ning page. http://www. library20.org/.

McKiernan, Gerry (2010a). Mobile libraries Weblog. http://mobilelibraries.blogspot.com/.

McKiernan, Gerry (2010b). Online social networks. Weblog. http:// onlinesocialnetworks.blogspot.com/.

McKiernan, Gerry (2010c). Classroom instruction in facebook. Facebook page. http://www.Facebook.com/group.php? gid $=2416166855$.

McKiernan, Gerry (2010d). Facebook SciFinder scholar interest group. Facebook page. http://www.Facebook.com/group.php? gid $=6035271802$.

McKiernan, Gerry (2010e). Facebook chemistry-information-sources-information group. http://www.Facebook.com/posted. php?id $=6155366866$.

Murphy, J., \& Moulaison, H. (2009, March). Social networking literacy competencies for librarians: exploring considerations and engaging participation. In The fourteenh National Conference of the Association of College and Research Libraries. Chicago: Association of College and Research Libraries.

Nijboer, Jelke, \& Hammelburg, Esther (2009). Extending media literacy: a new direction for libraries. New Library World, 111(1), 36-45. http://www.emeraldinsight.com/10.1108/ 03074801011015676.

Plan Alba. (2010). Plan Alba wiki site. http://planalba.pbworks.com.

Projet:P8. (2009). Project P8 page web. http://fr.wikipedia.org/ wiki/Projet:P8.

Raad voor Cultuur (RvC). (2005). Mediawijsheid: de ontwikkeling van nieuw burgerschap, Den Haag. Retrieved 18.04.10 from. http:// www.cultuur.nl/adviezen_vervolg.php?id $=4$ \&advies $=3997$.

REBIUN. (2009). Encuentro de responsables de ALFIN de REBIUN. http://www.alfared.org/blog/bibliotecas-universitarias/545.

REBIUN. (2010). VIII Jornadas CRAI Aplicación en el mun do laboral de las competencias informáticas e informacionales (C12). Retrieved 16.04.10, from. Valencia: Universidad. http://web. ua.es/es/jornadas-crai/.

Rollins, Debra Cox, Hutchings, Jessica, Goldsmith, Melissa, Ursula, Dawn, \& Fonseca, Anthony J (2009). Are we there yet?: the difficult road to re-create information literacy. October 2009. portal: Libraries and the Academy, 9(4). pp. 453-47.

SEDIC Sociedad Española de Documentación e Información Científica. (2010a). SEDIC Blog. http://comunidad20.sedic.es/.

SEDIC Sociedad Española de Documentación e Información Científica. (2010b). SEDIC Wiki. http://Wiki.sedic.es/index.php/ Biblioteca2.0+.

Sharples, S., Mitchell, E., \& Numbers, C. (2007). In L. Cohen (Ed.), Building library 2.0 into information literacy: A case study. Library 2.0 iniciative in academic library (pp. 114-132). Chicago: Association of College and research Libraries.

Spiranec, Sonja, \& Banek Zorica, Mihaela (2010). Information literacy 2.0: hype or discourse refinement? Journal of Documentation, 66(1), 140-153.
Universidad de Granada. (2008). Taller Unesco website. http:// medina-psicologia.ugr.es/ alfinunesco/index.htm.

Universidad de Sevilla. (2010a). Biblioteca. Weblogs. http://bib. us.es/aprendizaje_investigacion/guias_tutoriales/blogs-idesidweb.html.

Universidad de Sevilla. (2010b). Biblioteca. Subject guides Wiki site. http://bib.us.es/aprendizaje_investigacion/guias_ tutoriales/index-ides-idweb.html.

Universidad de Sevilla. (2010c). Biblioteca. Reference virtual chat site. http://bib.us.es/servicios/pregunte/ayuda_chat-idesidweb.html.

Universidad de Sevilla. (2010e). Biblioteca. Juego del trivial web site. http://wikialfin.pbworks.com/Juego-del-trivial.

Universidad de Sevilla. (2010a). Biblioteca de Centros de la Salud. http://bib.us.es/salud/aprendizaje_investigacion/Edublogsides-idweb.html Edublogs.

Universidad de Sevilla. (2010b). Biblioteca de Centros de la Salud. Cine y Medicina Wiki site. http://fama2.us.es:8080/Wikisalud.

Universidad de Sevilla. (2009). Biblioteca de Humanidades. Innovación docente Wiki. http://innovaciondocente.pbworks.com/.

Universidad de Sevilla. (2010). Biblioteca de la Escuela de Empresariales. El Turista despistado. http://turistadespistado. blogspot.com/ Weblog.

Universidad de Sevilla. Biblioteca de la facultad de Comunicación. Wikicomunica Wiki site. http://fama2.us.es:8080/ Wikicomunica/index.php/Portada.

Universidad Pablo de Olavide. (2010). Área de Biblioteconomía y Documentación. Asignatura Biblioteconomía Students Weblogs. http://www.netvibes.com/biblioeconomia09\#Blogs_de_ alumnos.

Universidad Pablo de Olavide. (2010a). Grado de Humanidades. Tic para Humanidades Wiki site. http://tichuma09.pbworks.com/.

Universidad Pablo de Olavide. (2010b). Grado de Humanidades. Tic para Humanidades Twitter account. http: //twitter.com/tichuma.

University of Sheffield. (2008). Introducing students to the idea of research. Case studies wiki. UK: Department of Information Studies. http://good.group.shef.ac.uk/wiki/index.php/ Introducing_students_to_the_idea_of_research.

University of Sheffield. (2010). Good practice Blog. UK: Department of Information Studies. http://good.group.shef.ac.uk/blog/? $\operatorname{tag}=$ web -20 .

Uribe, Alejandro (2009). El conocimiento y reconocimiento de los modelos de comportamiento informacional: Un aspecto necesario para los servicios de información Web 2.0 y la Alfabetización Informacional-DHI desde las bibliotecas. Retrieved 18.04.10, from. http://alfincolombia.blogspot. com/2009/12/el-conocimiento-y-reconocimiento-de-los. html.

Warlick, David (2009). Redefining literacy 2.0. Columbus, Ohio: Linworth Pub.

Webber, Sheila (2010a). Information literacy weblog. http:// information-literacy.blogspot.com/.

Webber, Sheila (2010b). Sheila webber netvibes page. http: / /www. netvibes.com/sheilawebber\#Home. 